\title{
Pembelajaran Matematika Realistik untuk meningkatkan Hasil Belajar Matematika Siswa
}

\author{
Fenny Anggreni, M.Pd1; Mariani, S.Pd ${ }^{2}$ \\ Dosen FTIK IAIN Langsa Kampus IAIN Langsa ${ }^{1}$ \\ Guru SD Negeri Kp. Baroh Langsa ${ }^{2}$ \\ fenny@iainlangsa.ac.id, mariani@gmail.com
}

\begin{abstract}
Realistic mathematics learning is a teaching approach that starts from "real" things for students. Fraction problems are often found in daily life and are felt difficult by most students in SDN Kp. Baroh Langsa so that student learning outcomes are still relatively low. The purpose of this research is to find out whether the use of Realistic Mathematics Learning can improve the learning outcomes of fourth-grade students of Semester II SDN Kp. Baroh Langsa. The approach used in this study is a qualitative approach and the type of research is classroom action research consisting of 2 cycles. The research subjects are grade IV students of SDN Kp. Baroh Langsa, amounting to 33 students. Data analysis used a comparative descriptive analysis technique by comparing conditions in cycle I and cycle II. Based on the results of research at the end of the second cycle it is known that there has been an increase in the class average of $29.16 \%$ from an average of the first cycle test of only 58.18 up to 75.15. Then completeness of student learning also increased by $87.50 \%$ from the first cycle that has been completed only 16 students to 30 students. So that most of the fourth-grade students of SDN Kp. Baroh Langsa experienced an increase in learning outcomes in fractional material. Thus it can be concluded that the use of realistic mathematics learning in fraction material can improve the learning outcomes of fourth-grade students of the second semester of SDN Kp. Baroh Langsa.
\end{abstract}

Keywords: Mathematics Learning Outcomes, Realistic, Student.

\begin{abstract}
Abstrak
Pembelajaran matematika realistik adalah pendekatan pengajaran yang bertitik tolak dari hal-hal yang "real" bagi siswa. Masalah pecahan sering ditemukan dalam kehidupan seharihari dan dirasakan sulit oleh sebagian besar siswa di SDN Kp. Baroh Langsa sehingga hasil belajar siswa masih tergolong rendah. Yang menjadi tujuan dalam penelitian ini adalah untuk mengetahui apakah pengunaan Pembelajaran Matematika Realistik dapat meningkatkan hasil belajar siswa kelas IV Semester II SDN Kp. Baroh Langsa. Pendekatan yang digunakan dalam penelitian ini adalah pendekatan kualitatif dan jenis penelitiannya adalah penelitian tindakan kelas yang terdiri atas 2 siklus. Subyek penelitian dalah siswa kelas IV SDN Kp. Baroh Langsa yang berjumlah 33 siswa. Analisis data menggunakan teknik analisis deskriptif komparatif dengan membandingkan kondisi pada siklus I dan siklus II. Berdasarkan hasil penelitian pada akhir siklus II diketahui telah terjadi peningkatan rata-rata kelas sebesar 29,16\% dari ratarata tes siklus I hanya 58,18 naik menjadi 75,15. Kemudian ketuntasan belajar siswa juga ada peningkatan sebesar 87,50\% dari siklus I yang sudah tuntas hanya 16 siswa menjadi 30 siswa. Sehingga sebagian besar siswa kelas IV SDN Kp. Baroh Langsa mengalami peningkatan hasil belajar pada materi pecahan. Dengan demikian dapat disimpulkan bahwa penggunaan pembelajaran matematika realistik pada materi pecahan dapat meningkatkan hasil belajar siswa kelas IV semester II SDN Kp. Baroh Langsa.
\end{abstract}

Kata kunci: Hasil Belajar Matematika, Realistik, Siswa. 


\section{A. Pendahuluan}

Perkembangan ilmu pengetahuan dan teknologi berkembang sangat pesat, sejalan dengan itu persaingan disegala bidang khususnya dibidang pendidikan harus mampu bersaing dengan negara yang berkembang sehingga dapat menghasilkan sumber daya manusia yang berkualitas. Oleh karena itu kita dituntut lebih terampil agar dapat mempertahankan hidup karena pada kenyataannya kehidupan kita selalu dihadapkan kepada berbagai masalah, sehingga diperlukan proses pembelajaran dalam hal ini.

Menurut Sardiman (2008: 20) Ada beberapa definisi tentang belajar, antara lain menurut Cronbach memberikan definisi: Learning is show by a change in behavior as a result of experience dan Harold Spears memberikan batasan : Learning is to observe, to read, to imatate, to try something themselves, to listen, to follow direction. Dari ketiga definisi diatas, maka dapat diterangkan bahwa belajar itu senantiasa merupakan perubahan tingkah laku atau penampilan dengan serangkaian kegiatan, misalnya dengan membaca, mengamati, mendengarkan, meniru dan lain sebagainya.

Pendapat di atas dipertegas oleh pendapat Slameto (2015: 2) yang mengatakan "Belajar adalah suatu proses usaha yang dilakukan sekarang untuk memperoleh suatu perubahan tingkah laku yang baru secara keseluruhan, sebagai hasil pengalamannya sendiri dalam interaksi lingkungannya". Berbagai masalah dalam kehidupan sehari-hari banyak mengaitkan matematika sebagai pemecahan masalahnya, Menurut Johnson dan Myklebust (dalam Abdurrahman,Mulyono, 2003: 252) Matematika adalah bahasa simbolis yang fungsi praktisnya untuk mengekspresikan hubungan-hubungan kuantitatif dan keruangan sedangkan fungsi teoritisnya adalah untuk memudahkan berfikir. Sehingga pembelajaran matematika sangat diperlukan dalam berbagai bidang kehidupan.

Dalam kondisi seperti demikian maka dibutuhkan siswa yang mempunyai prestasi belajar yang baik di dalam bidang matematika agar dapat terampil, kreatif dan inovatif. Untuk menghasilkan siswa yang mempunyai prestasi belajar yang baik, dibutuhkan kekreatifan guru di dalam menggunakan motode dan strategi yang tepat sehingga pembelajaran lebih 
bervariasi yang nantinya diharapkan dapat menarik minat siswa untuk belajar.

Menurut Slameto (2015: 92 ):“Guru harus menggunakan banyak metode pada waktu mengajar, variasi metode mengakibatkan penyajian bahan ajaran lebih menarik perhatian siswa, mudah diterima siswa, dan kelas menjadi hidup". Oleh karena itu, Guru harus menggunakan berbagai metode pada waktu mengajar agar dapat menarik perhatian dan minat siswa didalam belajar sehingga siswa tidak akan bosan belajar matematika.

Kenyataan yang terjadi di lapangan masih banyak siswa yang tidak menggemari pembelajaran matematika bahkan siswa tidak tertarik mempelajari matematika karena mereka menganggap pelajaran matematika sangat sulit dan bersifat abstrak sehingga banyak materi pelajaran tidak bisa dikuasai dengan baik. Hal ini bisa terjadi karena tidak adanya strategi yang dilakukan oleh guru agar para siswanya bisa menyukai matematika. Selain itu proses pembelajaran matematika hanya berpusat pada guru, guru hanya mengajar dengan metode ceramah sehingga siswa tidak bisa berkreasi dan mencari sendiri persoalan dalam matematika, siswa hanya mendengar, mencatat dan menjawab soal tanpa bisa mengkonstruksi jawabannya sendiri. Untuk menanggulangi hal tersebut sudah seharusnya kita mengganti pendekatan pembelajaran yang berpusat pada guru dengan pembelajaran yang berpusat pada siswa, karena model pendekatan yang berpusat pada siswa diharapkan lebih efektif dalam menunjang ketertiban dan partisipasi lebih mendalam, tidak hanya sebatas yang disampaikan oleh guru.

Berdasarkan hal di atas salah satu pembelajaran yang dapat digunakan adalah melalui pendekatan realistik. Menurut Zulkardi (2007: 7) Pembelajaran Matematika Realistik adalah pendekatan pengajaran yang bertitik tolak dari hal-hal yang real bagi siswa, menekankan keterampilan (process of doing mathematics), berdiskusi dan berkolaborasi, berargumentasi dengan teman sekelas sehingga mereka dapat menemukan sendiri (student inventing sebagai kebalikan dari teacher telling) dan pada akhirnya menggunakan matematika itu untuk menyelesaikan masalah baik secara individu maupun kelompok. Pada pendekatan ini peran guru tidak 
lebih dari seorang fasilitator, moderator,atau eveluator sementara siswa berpikir, mengkomunikasikan (reasoning), melatih nuansa demokrasi dengan menghargai pendapat orang lain.

Graveimeijer (Purnama, 2007: 11) menyatakan bahwa dalam mendesain pembelajaran matematika realistik terdapat tiga prinsip dasar, yaitu :

1. Penemuan kembali secara terbimbing dan proses matematisasi secara progresif (guide reinvention and progressive mathematizing).

2. Fenomena yang bersifat mendidik (didactical phenomenology) situasi dimana topik matematika yang diberikan diterapkan untuk dua alasan yaitu pertama: menyatakan berbagai kegunaan yang harus diantisipasi dalam perintah, kedua: mempertimbangkan kecocokan sebagai pengaruh yang kuat untuk proses matematika progresif.

3. Mengembangkan model sendiri (self-developed models). Pertama: model situasi nyata dari kebiasaan siswa dengan proses generalisasi dan formalisasi model menjadi satu kesatuan dalam diri siswa. Model yang dikembangkan sendiri oleh siswa berperan menjembantani perbedaan antara pengetahuan informal.

Greveimeijer (Muklis, 2005: 23) mengemukakan 5 karakteristik pendekatan realistik, yaitu:

1. Menggunakan masalah kontekstual (the use of contex)

Pembelajaran diawali dengan menggunakan masalah kontekstual, tidak dimulai dengan sistem formal. Masalah kontekstual yang diangkat sebagai topik pembelajaran harus merupakan masalah sederhana yang dikenal siswa.

2. Menggunakan model (the use models, bridging by vetical instruments) Istilah model berkaitan dengan model situasi yang dikembangkan sendiri oleh siswa sebagai jembatan antara level pemahaman yang satu ke level pemahaman yang lain dengan menggunakan instrumen vertikal seperti model-model, skema-skema, diagram-diagram, simbol dan sebagainya.

3. Menggunakan kontribusi murid (student contribution) 
Kontribusi yang besar pada proses belajar mengajar diharapkan datang dari siswa, artinya semua pikiran (konstruksi dan produksi) siswa diperhatikan.

4. Proses pengajaran yang interaktif (interaktivity)

Mengoptimalkan proses belajar mengajar dan terdapat interaksi yang terus menerus antar siswa dengan siswa, siswa dengan guru dan siswa dengan sarana dan prasarana merupakan hal penting dalam pembelajaran matematika realistik, sedemikian hingga setiap siswa mendapat manfaat positif dari interaksi tersebut.

5. Terintegrasi dengan topik lainnya (intertwining)

Matematia merupakan ilmu yang terstruktur, oleh karena itu keterkaitan dan keterintegrasian antar topik (unit pelajaran) harus dieksplorasi untuk mendukung terjadinya proses belajar mengajar yang lebih bermakna sehingga memunculkan pemahaman secara serentak.

Pecahan merupakan materi yang penting di sekolah dasar, karena merupakan dasar dalam belajar matematika lebih lanjut. Selain itu juga banyak digunakan dalam kehidupan sehari-hari dan dalam bidang ilmu lainnya. Berdasarkan pengalaman saya disekolah hasil belajar siswa di SD.N.Kp.Baroh Langsa khususnya pada materi pecahan masih tergolong rendah karena pecahan merupakan materi yang kompleks sehingga siswa kesulitan dalam memahami materi pecahan dan menyelesaikan soal-soal yang terkait dengan pecahan.

Sehubungan dengan hal tersebut, maka sudah seharusnya dalam mengajar materi pecahan di SD diperlukan suatu perangkat pembelajaran yang efektif sehingga dapat meningkatkan hasil belajar siswa. Oleh karena itu penggunaan pembelajaran matematika realistik dirasakan cocok digunakan pada materi pecahan di SD.

\section{B. Metode}

Penelitian ini dilaksanakan di SDN Kp. Baroh Langsa pada mata pelajaran matematika materi pecahan di kelas IV. Subjek pada penelitian berjumlah 33 siswa. Data yang dikumpulkan dari siswa meliputi data hasil 
tes tertulis. Tes tertulis dilaksanakan pada setiap akhir siklus yang terdiri atas materi pecahan. Selain siswa sebagai sumber data, penulis juga menggunakan teman sejawat sesama guru kelas sebagai sumber data. Penelitian ini pengumpulan data menggunakan teknik tes dan non tes. Tes tertulis digunakan pada akhir siklus I dan II yang terdiri atas materi pecahan. Teknik non tes meliputi teknik observasi dan wawancara. Observasi digunakan pada saat pelaksanaan penelitian tindakan kelas pada siklus I dan II. sedangkan wawancara digunkan untuk mengetahui secara langsung perasaan siswa saat pembelajaran berlangsung.

Analisis data yang digunakan dalam penelitian ini adalah teknik analisis deskriptif, yang meliputi:

1. Analisis deskriptif komparatif hasil belajar dengan cara membandingkan hasil belajar siswa pada siklus I dengan siklus II .

2. Analisis deskriptif kualitatif hasil observasi dengan cara membandingkan hasil observasi dan refleksi pada siklus I dan siklus II.

Indikator keberhasilan penelitian ini dengan menggunakan hasil nilai pembelajaran patokan KKM 60. Kunandar (2009:44) mendefinisikan Penelitian Tindakan Kelas (PTK) sebagai suatu penelitian tindakan (action research) yang dilakukan oleh guru yang sekaligus sebagai peneliti dikelasnya atau bersama-sama dengan orang lain (kolaborasi) dengan jalan merancang, melaksanakan dan merefleksi tindakan secara kolaboratif dan partisipatif yang bertujuan untuk memperbaiki atau meningkatkan mutu (kualitas) proses pembelajaran dikelasnya melalui suatu tindakan (treatment) tertentu dalam suatu siklus.

Konsep pokok penelitian tindakan model Kurt Lewin terdiri dari empat komponen yaitu perencanaan(planning)-tindakan(acting)-pengamatan (observing) -refleksi(reflecting), hubungan keempat komponen tersebut dipandang sebagai siklus yang dapat digambarkan sebagai berikut: 


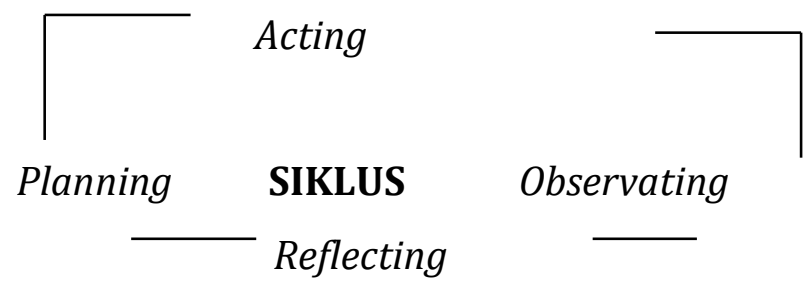

Gambar 1. Model Action Research menurut Kurt Lewin

(Kunandar ,2009:20)

Penelitian ini terdiri atas 2 siklus. Setiap siklus terdiri atas perencanaan, tindakan, pengamatan dan refleksi.

Siklus I

1) Perencanaan (planning), terdiri atas kegiatan: Penyusunan Rencana Pelaksanaan Pembelajaran (RPP); dan Menyiapkan LKS.

2) Tindakan (acting), terdiri atas kegiatan; Pelaksanaan program pembelajaran sesuai dengan jadwal, Membagi siswa dalam enam kelompok, Proses pembelajaran dengan menggunakan pembelajaran matematika realistik pada materi pecahan dengan indikator menentukan pecahan dari satu kesatuan yang utuh, Mengadakan observasi tentang proses pembelajaran, Mengadakan tes tertulis, dan Penilaian hasil tes tertulis.

3) Pengamatan (observing), yaitu mengamati proses pembelajaran dan menilai hasil tes sehingga diketahui hasilnya. Atas dasar hasil tersebut digunakan untuk merencanakan tindak lanjut pada siklus berikutnya.

4) Refleksi (reflecting), yaitu menyimpulkan pelaksanaan hasil tindakan pada siklus I.

\section{C.Hasil DAN PEMBAHASAN}

\section{Deskripsi Hasil Siklus I}

\section{1) Perencanaan Tindakan}

Adapun hal-hal yang disiapkan oleh peneliti pada tahap ini adalah; Rencana Pelaksanaan Pembelajaran (RPP) dan Lembar Kerja Siswa (LKS) 


\section{2) Pelaksanaan Tindakan}

Pelaksanaan tindakan didasarkan pada RPP yang telah disusun yang terdiri dari tahap awal, tahap inti dan tahap akhir, yaitu tahap Awal dialokasikan selama 15 menit. Kegiatan pembelajaran dimulai dengan guru menanyakan kembali contoh bentuk pecahan. Guru memberikan pengarahan tentang pentingnya materi yang akan dipelajari serta kaitannya dalam kehidupan sehari-hari. Tahap Inti dialokasikan selama 75 menit. Guru membagi siswa dalam enam kelompok serta meminta siswa duduk pada kelompok masing-masing. Guru meminta siswa mengerjakan LKS bersama anggota kelompoknya. Bersama teman kelompoknya siswa menyelesaikan soal LKS tentang masalah kontekstual dan menyelesaikannya sesuai dengan cara mereka masing-masing. Guru membimbing kelompok belajar. Guru meminta perwakilan kelompok untuk mempresentasikan hasil diskusinya di depan kelas. Guru memberikan penghargaan bagi kelompok yang terbaik. Guru mengadakan tes akhir berupa tes tertulis kepada siswa. Tahap Akhir dialokasikan selama 15 menit. Guru membimbing siswa untuk menarik kesimpulan. Siswa membuat rangkuman.

a) Wawancara; Wawancara dilaksanakan setelah kegiatan tatap muka selesai. Kegiatan wawancara dilaksanakan oleh guru terhadap beberapa siswa. Wawancara diperlukan untuk mengetahui sejauh mana perasaan siswa dalam memahami materi pecahan dari kesatuan yang utuh dengan menggunakan pembelajaran matematika realistik. Hasil wawancara juga digunakan sebagai bahan refleksi.

b) Observasi; Observasi dilaksanakan pada seluruh kegiatan tatap muka, dalam hal ini observasi dilakukan oleh satu observer yaitu guru kelas (teman sejawat) pada SDN Kp. Baroh Langsa. Observasi ini dilaksanakan untuk mengetuhui secara detail keaktifan, prilaku, presentasi dan kerjasama siswa dalam memahami pecahan dari satu kesatuan yang utuh. Hasil observasi digunakan sebagai bahan refleksi dan untuk merencanakan rencana tindakan pada siklus II. 


\section{3) Observasi}

Hasil observasi pada siklus I dapat dideskripsikan seperti pada tabel 1. berikut ini.

Tabel 1. Hasil Rekap Nilai Tes Siklus I

\begin{tabular}{|c|c|c|c|c|c|}
\hline \multirow{2}{*}{ No } & \multicolumn{2}{|c|}{ Hasil } & \multirow{2}{*}{$\begin{array}{c}\text { Arti } \\
\text { Lambang }\end{array}$} & \multirow{2}{*}{$\begin{array}{l}\text { Jumlah } \\
\text { Siswa }\end{array}$} & \multirow{2}{*}{ Persentase } \\
\hline & Angka & Huruf & & & \\
\hline 1 & $85-100$ & $\mathrm{~A}$ & Sangat baik & 2 & $6,06 \%$ \\
\hline 2 & $75-84$ & $\mathrm{~B}$ & Baik & 5 & $15,15 \%$ \\
\hline 3 & $65-74$ & $\mathrm{C}$ & Cukup & 4 & $12,12 \%$ \\
\hline 4 & $55-64$ & $\mathrm{D}$ & Kurang & 5 & $15,16 \%$ \\
\hline 5 & $<54$ & $\mathrm{E}$ & $\begin{array}{l}\text { Sangat } \\
\text { Kurang }\end{array}$ & 17 & $51,51 \%$ \\
\hline \multicolumn{4}{|c|}{ Jumlah } & & $100 \%$ \\
\hline
\end{tabular}

Dari hasil siklus I, menunjukkan bahwa hasil yang mencapai nilai A (sangat baik) adalah 2 siswa (6,06 \%), sedangkan yang mendapat nilai B (baik) adalah 5 siswa (15,15 \%), sedangkan yang mendapat nilai C (Cukup) adalah 4 siswa (12,12\%), sedangkan yang mendapat nilai D (kurang) adalah 5 siswa (15,16\%), sedangkan yang mendapat nilai E (sangat kurang) adalah 17 siswa (51,51\%). Nilai kriteria ketuntasan minimal (KKM) pada materi pecahan adalah 60. Berdasarkan nilai KKM tersebut maka siswa yang tuntas sebanyak 16 siswa atau 48,49\%, sedangkan yang belum tuntas sebanyak 17 siswa atau 51,51 \% dari 33 jumlah seluruh siswa. Adapun dari hasil nilai siklus I dapat dijelaskan bahwa perolehan nilai tertinggi adalah 90, nilai terendah 40 , dengan nilai rata-rata sebesar 5,82.

\section{4) Refleksi}

Berdasarkan hasil tes siklus I siswa yang belum mencapai ketuntasan sebanyak 17 siswa (51,51\%) sedangkan yang tuntas hanya 16 siswa $(48,49 \%)$, hasil tersebut belum optimal. hal ini bisa dilihat dari hasil observasi bahwa sebagian siswa belum terbiasa dengan kondisi belajar dengan menggunakan pembelajaran matematika realistik sehingga siswa 
kurang aktif dan serius dalam belajar. Untuk memperbaiki kelemahan pembelajaran pada siklus I, maka pada pelaksanaan siklus II guru harus lebih intensif membimbing siswa yang mengalami kesulitan dalam belajar sehingga siswa akan lebih serius dalam belajar.

\section{B. Deskripsi Hasil Siklus II}

Berdasarkan hasil refleksi pada siklus I, maka pelaksanaan tindakan pada siklus II dapat dideskripsikan sebagai berikut:

\section{1) Perencaan Tindakan}

Dalam siklus II pada hakikatnya merupakan perbaikan atas kondisi siklus

I. Adapun hal-hal yang disiapkan oleh peneliti pada tahap ini adalah Rencana Pelaksanaan Pembelajaran (RPP) dan Lembar Kerja Siswa (LKS)

\section{2) Pelaksanaan tindakan}

a) Pelaksanaan Tatap Muka

Pelaksanaan tindakan pada siklus II dilakukan sesuai dengan RPP yang sudah dipersiapkan. Tindakan pada siklus II ini dibagi menjadi 3 kegiatan yaitu: tahap awal, tahap inti, dan tahap akhir.

1. Tahap Awal ini dialokasikan waktu 15 menit. Kegiatan pembelajaran dimulai dengan menanyakan kendala yang dihadapi siswa ketika menyelesaikan soal yang lalu. Guru memotivasi siswa agar lebih fokus lagi dalam pembelajaran.

2. Tahap Inti dilakukan selama 75 menit. Guru meminta siswa duduk pada kelompok masing-masing. Guru meminta siswa mengerjakan LKS bersama anggota kelompoknya dengan baik dan benar. Bersama teman kelompoknya siswa menyelesaikan soal LKS tentang masalah kontekstual dan menyelesaikannya sesuai dengan cara mereka masing-masing. Guru membimbing siswa dalam menyelesaikan LKS. Guru meminta perwakilan kelompok untuk mempresentasikan hasil diskusinya di depan kelas. Setelah itu guru memberikan penghargaan bagi kelompok yang terbaik. Selanjutnya guru memberikan tes akhir berupa tes tertulis kepada siswa. 
3. Tahap Akhir selama 15 menit. Pada tahap ini guru membimbing siswa untuk menarik kesimpulan. Guru juga meminta siswa mengulang materi yang telah dipelajari dirumah.

\section{3) Wawancara}

Wawancara dilaksanakan setelah kegiatan tatap muka selesai. Kegiatan wawancara dilaksanakan oleh guru terhadap beberapa siswa. Wawancara diperlukan untuk mengetahui sejauh mana perasaan siswa dalam memahami materi pecahan dari kesatuan yang utuh dengan menggunakan pembelajaran matematika realistik. Hasil wawancara juga digunakan sebagai bahan refleksi.

\section{4) Observasi}

Observasi dilaksanakan pada seluruh kegiatan tatap muka, dalam hal ini observasi dilakukan oleh satu observer yaitu guru kelas (teman sejawat) pada SDN Kp. Baroh Langsa. Observasi ini dilaksanakan untuk mengetuhui secara langsung aktivitas siswa dalam proses pembelajaran. Hasil onservasi digunakan sebagai bahan refleksi. Hasil observasi pada siklus II dapat dideskripsikan seperti pada tabel 2.

Tabel 2. Hasil Rekap Nilai Tes Siklus II

\begin{tabular}{|c|c|c|c|c|c|}
\hline \multirow{2}{*}{ No } & \multicolumn{2}{|c|}{ Hasil } & \multirow{2}{*}{ Arti } & $\begin{array}{c}\text { Jumlah } \\
\text { Siswa }\end{array}$ & Persentase \\
\cline { 2 - 4 } & Angka & Huruf & & & \\
\hline 1 & $85-100$ & A & Sangat baik & 7 & $21,21 \%$ \\
\hline 2 & $75-84$ & B & Baik & 13 & $39,39 \%$ \\
\hline 3 & $65-74$ & C & Cukup & 6 & $18,18 \%$ \\
\hline 4 & $55-64$ & D & Kurang & 7 & $21,21 \%$ \\
\hline 5 & $<54$ & E & Sangat Kurang & - & - \\
\hline \multicolumn{7}{|c|}{ Jumlah } & 33 & $100 \%$ \\
\hline
\end{tabular}

Dari hasil siklus II, menunjukkan bahwa siswa yang mencapai nilai A (sangat baik) adalah 7 siswa (21,2\%), sedangkan yang mendapat nilai B (baik) adalah 13 siswa (39,39\%), sedangkan yang mendapat nilai C (Cukup) adalah 6 siswa (18,18\%), sedangkan yang mendapat nilai D (kurang) adalah 7 siswa (21,21\%), sedangkan yang mendapat nilai E (sangat kurang) tidak 
ada. Berdasarkan data tersebut diatas bahwa siswa yang mencapai ketuntasan sebanyak 30 siswa $(90,90 \%)$ yang berarti sudah ada peningkatan. Rata-rata kelas pun menjadi meningkat.

\section{5) Refleksi}

Berdasarkan nilai hasil siklus I dan nilai hasil siklus II dapat diketahui bahwa pembelajaran matematika realistik dapat meningkatkan hasil belajar siswa khususnya pada materi pecahan. Untuk lebih jelasnya pada tabel berikut dipaparkan refleksi perbandingan pada siklus I.dan siklus II.

Tabel 3. Perbandingan Hasil Nilai Tes Siklus I dan Siklus II

\begin{tabular}{|c|c|c|c|}
\hline \multirow{2}{*}{ No } & \multirow{2}{*}{ Hasil tes } & \multicolumn{2}{|c|}{ Jumlah siswa yang berhasil } \\
\cline { 3 - 4 } & & Siklus I & Siklus II \\
\hline 1 & $\mathrm{~A}(85-100)$ & 2 & 7 \\
\hline 2 & $\mathrm{~B}(75-84)$ & 5 & 13 \\
\hline 3 & $\mathrm{C}(65-74)$ & 4 & 6 \\
\hline 4 & $\mathrm{D}(55-64)$ & 5 & 7 \\
\hline 5 & $\mathrm{E}(<54)$ & 17 & - \\
\hline \multicolumn{2}{|c}{ Jumlah } & $\mathbf{3 3}$ & $\mathbf{3 3}$ \\
\hline
\end{tabular}

Perbandingan Ketuntasan Belajar siswa tampak pada tabel dibawah ini, jika dibandingkan hasil siklus I dan siklus II dapat diambil kesimpulan bahwa pada siklus II jumlah siswa yang tuntas lebih banyak yaitu sebanyak 30 siswa.

Tabel 4. Perbandingan Ketuntasan Belajar antara Siklus I dan Siklus II

\begin{tabular}{|c|c|c|c|c|c|}
\hline \multirow{2}{*}{ No } & \multirow{2}{*}{ Ketuntasan } & \multicolumn{4}{|c|}{ Jumlah Siswa } \\
\cline { 3 - 6 } & & \multicolumn{2}{|c|}{ Siklus I } & \multicolumn{2}{c|}{ Siklus II } \\
\cline { 3 - 6 } & & Jumlah & Persentase & Jumlah & Persentase \\
\hline 1 & Tuntas & 16 & $48,49 \%$ & 30 & $90,90 \%$ \\
\hline 2 & Belum Tuntas & 17 & $51,51 \%$ & 3 & $9,10 \%$ \\
\hline \multicolumn{2}{|c|}{ Jumlah } & $\mathbf{3 3}$ & $\mathbf{1 0 0 \%}$ & $\mathbf{3 3}$ & $\mathbf{1 0 0 \%}$ \\
\hline
\end{tabular}

Peningkatan hasil rata-rata kelas nampak ada perubahan dari siklus I dengan siklus II. Peningkatan nilai rata-rata kelas dapat dilihat dari tabel 5. di bawah ini: 
Tabel 5. Perbandingan nilai rata-rata Siklus I dan Siklus II

\begin{tabular}{|c|c|c|c|}
\hline No & Keterangan & Siklus I & Siklus II \\
\hline 1 & Nilai tertinggi & 90 & 100 \\
\hline 2 & Nilai terendah & 40 & 55 \\
\hline 3 & Nilai rata- rata & 58,18 & 75,15 \\
\hline
\end{tabular}

Berdasarkan dari paparan di atas dapat disimpulkan bahwa Penggunaan Pembelajaran Matematika Realistik dapat meningkatkan hasil belajar siswa khususnya pada materi pecahan. Hal ini dapat dilihat dari kenaikan jumlah siswa yang tuntas, pada siklus I siswa yang tuntas sebanyak 16 siswa $(48,49 \%)$ sedangkan pada siklus II naik menjadi 30 siswa $(90,90 \%)$. Rata-rata nilai siswa juga mengalami kenaikan, di siklus I rata-rata nilai siswa sebesar 58,18 sedangkan disiklus II naik menjadi 75,15.

Berdasarkan hasil observasi dalam kegiatan pembelajaran dapat disimpulkan bahwa kegiatan siswa pada siklus II lebih baik dari pada siklus I hal ini terjadi karena siswa sudah terbiasa dengan Pembelajaran Matematika Realistik sehingga siswa aktif dan kreatif di dalam proses pembelajaran, siswa juga sudah biasa bekerja sama dengan baik dan mempresentasikan jawabannya.

\section{Pembahasan Tiap Siklus dan Antar Siklus}

Proses pembelajaran pada siklus I dilihat dari hasil observasi sebagian siswa belum terbiasa dengan kondisi belajar dengan menggunakan pembelajaran matematika realistik sehingga siswa kurang aktif dan serius dalam belajar, siswa juga kurang bisa bisa bekerjasama dengan baik bersama temannya, serta siswa kurang bisa mempresentasikan hasil kerjanya di depan kelas. Proses pembelajaran pada siklus II dari hasil observasi. Sudah menunjukkan perbaikan dari siklusII, siswa sudah terbiasa dengan kondisi belajar yang menggunakan pembelajaran matematika realistik sehingga siswa sudah aktif dan serius dalam belajar. Siswa juga sudah bisa bekerjasama dengan baik bersama temannya, serta siswa sudah bisa mempresentasikan hasil kerja di depan kelas. 
Dengan melihat perbandingan hasil tes siklus I dan siklus II terdapat peningkatan yang cukup signifikan, baik dilihat dari ketuntasan belajar maupun hasil perolehan nilai rata-rata kelas. Dari 33 siswa masih ada 3 siswa yang belum mencapai ketuntasan, hal ini memang anak tersebut harus diberikan pelayana yang khusus, namun walaupun demikian anak tersebut tetap aktif dan sangat semangat dalam belajar. Sedangkan ketuntasan ada peningkatan sebesar $87,50 \%$ dibanding siklus I. Sedangkan nilai tertinggi pada siklus II sudah ada peningkatan dengan mendapat nilai 100 sebanyak 4 siswa. Dari nilai rata-rata kelas pada siklus II meningkat sebesar 29,16\% dibandingkan dengan nilai rata-rata kelas pada siklus I.

Proses pembelajaran juga berlangsung sangat baik dibandingkan pada siklus I sehingga hasil belajar siswa juga meningkat. Secara umum dapat disimpulkan bahwa melalui penggunaan pembelajaran matematika realistik dapat meningkatkan hasil belajar siswa pada materi pecahan.

\section{Kesimpulan}

Berdasarkan penelitian ini dapat disimpulkan bahwa Penggunaan Pembelajaran Matematika Realitik pada materi pecahan dapat meningkatkan hasil belajar siswa kelas IV Semester II di SDN Kp. Baroh Langsa. Pada akhir siklus I, siswa yang mencapai ketuntasan belajar sebanyak 58,18 (16 siswa), dan siswa yang belum tuntas sebanyak 51,51\% (17 siswa), sedangkan pada akhir siklus II siswa yang tuntas sebanyak 90,90\% (30 siswa) dan yang belum tuntas sebanyak 9,10\% (3 siswa). Dengan rata-rata nilai kelas siklus I 58,18 dan rata-rata kelas siklus II 75,15. secara keseluruhan rata-rata kelas mencapai kenaikan sebesar 29,89\%, dan ketuntasan belajar siswa secara keseluruhan mencapai peningkatan sebesar 87,50\%. Adapun hasil non tes observasi terhadap proses belajar menunjukkan perubahan yang sangat baik, karena siswa sudah aktif dalam proses pembelajaran. 


\section{E. SARAN}

Selain itu, beberapa saran yang ingin disampaikan adalah sebagai berikut :

1. Penggunaan pembelajaran matematika realistik dapat meningkatkan hasil belajar siswa pada materi pecahan sehingga perlu diterapkan pada materi lain.

2. Dengan adanya pembelajaran matematika realistik dapat menumbuhkan keaktifan antar siswa, maka baik untuk dikembangkan.

3. Informasi yang diperoleh dari penelitian ini diharapkan dapat digunakan sebagai bahan peneliti lebih lanjut.

4. Diharapkan untuk guru khususnya guru matematika agar dapat menerapkan pembelajaran matematika realistik dalam kegiatan belajar mengajar di sekolah.

\section{UCAPAN TERIMA KASIH}

Penulis mengucapkan terima kasih kepada para guru danstaf SD N Kp. Baroh yang telah memberi dukungan terhadap penelitian ini.

\section{DAFTAR PUSTAKA}

Abdurrahman,Mulyono. 2008. Pendidikan Bagi Anak Berkesulitan Belajar. Rineka Cipta. Jakarta

Kunandar. 2009. Langkah Mudah Penelitian Tindakan Kelas. Jakarta: Rajawali Pers.

Kusumah, Wijaya \& Dedi Dwitagama. 2009. Mengenal Penelitian Tindakan Kelas.: PT.Indeks, Jakarta

Mukhlis. 2005. Pembelajaran Matematika Realistik untuk Materi Pokok Perbandingan di Kelas VII SMP Negeri 1 Pallangga. Tesis PPs Unesa. Surabaya.

Mulyasa,E. 2005. Menjadi Guru Profesional. Cetakan Ketiga. Bandung: PT.Remaja Rosdakarya.

Mustaqim,Burhan \& Ary Astuti. 2008. Matematika untuk SD dan MI kelas IV. Jakarta: Pusat Perbukuan Departemen Pendidikan Nasional. 
Purnama, Sari Vidia. 2007. Interaksi Siswa dalam Pembelajaran Matematika Realistik pada Materi Keliling dan Luas Persegi Panjang di Kelas IV MIN Rukoh Banda Aceh. Banda Aceh: FKIP Unsyiah

Sardiman. 2008. Interaksi dan Motivasi Belajar Mengajar. Jakarta: PT. Raja Grafindo Persada

Slameto. 2015. Belajar dan Faktor-Faktor yang Mempengaruhi. Penerbit Rineka Cipta. Jakarta 